\title{
PENGARUH KEPEMIMPINAN KEPALA SEKOLAH TERHADAP MOTIVASI KERJA DAN KINERJA GURU
}

\author{
Nasrun \\ Fakultas Ilmu Pendididkan, Universitas Negeri Medan \\ Jl. Williem Iskandar Psr V Kotak Pos 1589 - Medan \\ Email: nasrun.nst@gmail.com
}

\begin{abstract}
The Influence of Principal Leadership on Teachers' Motivation and Their Performance. The purpose of this study to determine the effect of school leadership on work motivation and the performance of teachers. This type of research used in this research is explanatory research with methods of ex post facto basis that the research carried out relatively non-experimental. The population in this study were teachers in SMA Medan 241 teachers. This research uses descriptive statistical analysis and analysis infrensial. The results coefficient values obtained between the leadership of the principal lines of work motivation of teachers for 0,249 and the path coefficient between the leadership of the principal on teacher performance amounted to 0,156 . This shows that the school leadership have a significant influence on the motivation and performance of teachers.
\end{abstract}

Keywords: school leadership, motivation, teacher performance

\begin{abstract}
Abstrak: Pengaruh Kepemimpinan Kepala sekolah terhadap Motivasi kerja dan Kinerja Guru. Tujuan penelitian ini untuk mengetahui pengaruh kepemimpinan kepala sekolah terhadap motivasi kerja dan kinerja guru. Jenis penelitian yang digunakan dalam penelitian ini adalah explanatory research dengan metode expost facto dengan pertimbangan bahwa penelitian yang dilaksanakan tergolong non eksperimen. Populasi dalam penelitian ini adalah guru di SMA Negeri Kota Medan sebanyak 241 guru. Penelitian ini mengunakan analisis statistik deskriptif dan analisis infrensial. Hasil penelitian didapatkan nilai koefisien jalur antara kepemimpinan kepala sekolah terhadap motivasi kerja guru sebesar 0,249 dan koefisien jalur antara kepemimpinan kepala sekolah terhadap kinerja guru sebesar 0,156. Hal ini menunjukkan bahwa kepemimpinan kepala sekolah memberikan pengaruh yang signifikan terhadap motivasi kerja dan kinerja guru.
\end{abstract}

Kata kunci: kepemimpinan kepala sekolah, motivasi, kinerja guru

Pendidikan di Indonesia bertujuan untuk mengembangkan peserta didik agar menjadi manusia yang beriman dan bertakwa kepada Tuhan Yang Maha Esa, serta berahklak mulia, sehat, berilmu, cakap, kreatif, mandiri, dan menjadi warga negara yang demokratis serta bertanggung jawab (Undang-undang Nomor 20 Tahun 2003 Bab II Pasal 3). Dalam rangka mencapai tujuan pendidikan tersebut, seorang pendidik yang melakukan proses pembelajaran perlu melakukan serangkaian kegiatan yang dimulai dari perencanaan, menentukan strategi, pemilihan materi dan metode pembelajaran, sampai pada penilaian yang tepat.

Pembentukan kinerja guru yang efektif merupakan hasil kombinasi dari banyak faktor, seperti komitmen, pertumbuhan pribadi, lingkungan sekolah, budaya yang berlaku, inovasi guru dan lain-lain. Semua faktorfaktor memiliki hubungan langsung atau tidak langsung dengan tindakan yang dilakukan oleh kepala sekolah. Kepala sekolah sebagai 
pimpinan tertinggi yang sangat berpengaruh dan menentukan kemajuan sekolah harus memiliki kemampuan administrasi, memiliki komitmen tinggi, dan luwes dalam melaksanakan tugasnya. Kepemimpinan kepala sekolah yang baik harus dapat mengupayakan peningkatan kinerja guru melalui program pembinaan kemampuan tenaga kependidikan. Oleh karena itu kepala sekolah harus mempunyai kepribadian atau sifat-sifat dan kemampuan serta keterampilan-keterampilan untuk memimpin sebuah lembaga pendidikan. Dalam perannya sebagai seorang pemimpin, kepala sekolah harus dapat memperhatikan kebutuhan dan kemampuan yang dimiliki oleh guru dan berusaha untuk meningkatkan kemampuan dan kinerja guru.

Kepemimpinan adalah kemampuan individu dalam mempengaruhi orang lain, memotivasi sejumlah orang agar bekerja sama dalam melaksanakan kegiatan-kegiatan yang terarah pada tujuan bersama yang melibatkan proses pendistribusian kekuasaan antara pemimpin dan anggota. Menurut Effendy (1981:16) bahwa setiap pemimpin sekurang-kurangnya memiliki tiga syarat, yakni pertama memiliki persepsi sosial (social perception) yaitu kecakapan untuk cepat melihat dan memahami perasaan, sikap, dan kebutuhan anggota kelompok. Kedua, kemampuan berpikir abstrak (ability in abstract thinking) yaitu kemampuan berabstraksi dibutuhkan oleh seorang pemimpin untuk dapat menafsirkan kecenderungan-kecenderungan kegiatan, baik di dalam maupun di luar kelompok, dalam kaitannya dengan tujuan kelompok dimana kemampuan tersebut memerlukan taraf intelegensia yang tinggi pada seorang pemimpin. Ketiga, keseimbangan emosional (emotional stability), pada diri seorang pemimpin harus terdapat kematangan emosional yang berdasarkan kesadaran yang mendalam akan kebutuhan, keinginan, cita-cita dan suasana hati, serta pengintegrasian kesemua hal tersebut ke dalam suatu kepribadian yang harmonis sehingga seorang pemimpin dapat turut merasakan keinginan dan cita-cita anggota kelompoknya Locke (1997:52) mengemukakan tiga pandangan menyangkut dengan kepemimpinan. Pertama, kepemimpinan menyangkut 'orang lain', bawahan atau pengikut, dan kesediaan mereka untuk menerima pengarahan dari pemimpin. Jika tidak ada pengikut, maka tidak akan ada pula pemimpin. Tanpa bawahan semua kualitas kepemimpinan seorang atasan akan menjadi tidak relevan. Terkandung makna bahwa para pemimpin yang efektif harus mengetahui bagaimana membangkitkan inspirasi dan menjalin relasi dengan pengikut mereka.Kedua, kepemimpinan merupakan suatu 'proses', agar bisa memimpin maka pemimpin mesti melakukan sesuatu, kepemimpinan lebih dari sekedar menduduki suatu posisi otoritas. Kendatipun posisi otoritas yang diformalkan mungkin sangat mendorong proses kepemimpinan, tetapi sekadar menduduki posisi itu tidak memadai untuk membuat seseorang menjadi pemimpin. Ketiga, kepemimpinan harus 'membujuk' orang-orang lain untuk mengambil tindakan. Pemimpin membujuk para pengikutnya lewat berbagai cara seperti menggunakan otoritas yang terlegitimasi, menciptakan model (menjadi teladan), penetapan sasaran, memberi imbalan/ hukuman, restrukturisasi organisasi, dan mengkomunikasikan sebuah visi.

Motivasi adalah mempersoalkan bagaimana caranya mengarahkan daya potensi bawahan agar mau bekerja secara produktif serta berhasil mencapai dan mewujudkan tujuan yang telah ditentukan. Menurut Hasibuan (2001:95) motivasi berasal dari kata dasar motif, yang mempunyai arti suatu perangsang, keinginan dan daya penggerak kemauan bekerja seseorang. Motivasi adalah pemberian daya penggerak yang menciptakan kegairahan kerja seseorang agar mereka mau bekerjasama dengan efektif dan terintegrasi dengan segala daya upayanya untuk mencapai kepuasan. Robbins (2001:166) motivasi adalah kesediaan untuk mengeluarkan tingkat upaya yang tinggi untuk tujuan organisasi yang dikondisikan oleh kemampuan upaya itu dalam memenuhi beberapa kebutuhan individual. Kebutuhan terjadi apabila tidak ada keseimbangan antara apa yang dimiliki dan apa yang diharapkan.

Kinerja adalah performance atau unjuk kerja. Kinerja dapat pula diartikan prestasi kerja atau pelaksanaan kerja atau hasil unjuk kerja. Minner (1992:612) mengemukakan kinerja merupakan kesesuaian perilaku yang diharapkan oleh organisasi. Ahli lain yaitu Griffin (1997:464) menyatakan bahwa kinerja adalah totalitas perilaku yang berhubungan dengan pekerjaan yang diharapkan organisasi untuk ditampilkan. Setiap 
guru berusahauntuk melaksanakan tugasnya dengan baik untuk menghasilkan hasil yang memuaskan guna tercapainya tujuan sebuah organisasi atau kelompok dalam suatu unit kerja. Jadi, kinerja guru merupakan hasil kerja dimana para guru mencapai persyaratan-persyaratan pekerjaan. Persyaratanpersyaratan tersebut biasanya telah ditetapkan dalam suatu organisasi, termasuk dalam lingkungan sekolah. Standar kinerja perlu dirumuskan untuk dijadikan acuan dalam mengadakan penilaian, yaitu dengan membandingkan apa yang dicapai dengan apa yang diharapkan. Standar kinerja dapat dijadikan patokan dalam mengadakan berbagai pertanggungjawaban terhadap apa yang telah dilaksanakan.

\section{METODE}

Dari beberapa teori yang dikemukakan di atas dapat disimpulkan bahwa kinerja merupakan suatu tindakan yang dilakukan oleh individu untuk diselesaikan dalam kurun waktu tertentu sehingga dapat diukur.

Berdasarkan tujuan penelitian adalah untuk mengetahui pengaruh kepemimpinan kepala sekolah terhadap motivasi kerja dan kinerja guru, maka jenis yang digunakan dalam penelitian ini adalah penelitian eksplanatoris. Metode yang digunakan dalam penelitian ini dapat digolongkan dalam metode expost facto dengan pertimbangan bahwa penelitian yang dilaksanakan tergolong non eksperimen. Menurut Kerlinger (2006:604) metode expost facto dapat digunakan pada penelitian eksperimen, dimana peneliti tidak melakukan intervensi terhadap variabel penelitian, karena manifestasi dari variabel tersebut telah muncul atau pada hakikatnya variabel tersebut tidak mungkin dapat dimanipulasi. Berdasarkan pengertian tersebut dapat diketahui bahwa penelitian explanatory dapat berguna untuk menjelaskan adanya pengaruh variabel yang diuji dengan menggunakan pengujian statistik.

Adapun hubungan antar variabel penelitian dapat disajikan pada gambar 1 sebagai berikut.

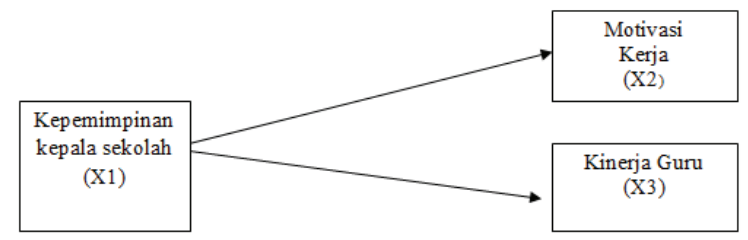

Gambar 1. Model Hipotesis Penelitian
Hipotesis yang akan diuji dalam penelitian ini adalah: " Pengaruh Kepemimpinan Kepala Sekolah (X1) Terhadap Motivasi Kerja (X2) dan Kinerja Guru (X3) di SMA Negeri Kota Medan".

Dalam penelitian ini adalah untuk mengetahui apakah ada pengaruh yang signifikan mengenai kepemimpinan kepala sekolah terhadap motivasi dan kinerja guru di SMA Negeri Kota Medan. Teknik analisis yang digunakan yaitu analisis deskriptif dan analisis inferensial.

\section{HASIL DAN PEMBAHASAN}

\section{Hasil}

Analisis deskriptif membahas skor rata-rata, skor minimum, skor maksimum, rata-rata, median, modus dan simpangan baku. Selain disajikan secara deskriptif, untuk mempermudah dalam memahami data hasil penelitian, data juga disajikan dalam bentuk distribusi frekuensi dan grafik histogram. Rangkuman hasil analisis deskriptif disajikan pada Tabel 1.

Selanjutnya berdasarkan hasil perhitungan mean skor ideal dan standar deviasi ideal, data kemudian diklasifikasikan dalam tiga kategori yaitu: tinggi, sedang, dan rendah dengan ketentuan sebagai berikut.

Jika X $: \geq$ Mean +1 .

Standar deviasi $=$ kategori tinggi

Jika X : Antara Mean \pm 1 .

Standar deviasi $=$ kategori sedang

Jika X : Mean - 1.

Standar deviasi $=$ kategori rendah

\section{Kepemimpinan Kepala Sekolah}

Data variabel kepemimpinan kepala sekolah (X1) terdiri dari empat indikator: (1) Karakteristik pribadi yaitu kemampuan dominasi mencakup keinginan untuk mengambil alih keputusan, kepercayaan diri, dan ekstrovet; (2) Kesadaran terdiri dari keinginan berprestasi, semangat tinggi dan kemampuan inisiatif; (3) Kecenderungan perilaku sosial yang terdiri dari ekspresi afeksi, pendengar yang baik, dan tingkat kebutuhan rendah untuk disukai; dan (4) kontrol locus internal terdiri dari optimis, ketahanan, dan konsisten. Sebaran data dan distribusi frekuensi skor variabel kepemimpinan kepala sekolah dapat dilihat melalui Tabel 2. 
Tabel 1 Rangkuman Statistik Deskriptif Data Penelitian

\begin{tabular}{lccc}
\hline \multicolumn{1}{c}{ Analisis } & \multicolumn{3}{c}{ Variabel } \\
\cline { 2 - 4 } & $\mathbf{X}_{\mathbf{1}}$ & $\mathbf{X}_{\mathbf{2}}$ & $\mathbf{X}_{\mathbf{3}}$ \\
\hline Banyak data (N) & 241 & 241 & 241 \\
Skor Minimum & 63 & 82 & 36 \\
Skor Maksimum & 173 & 170 & 64 \\
Range & 110 & 88 & 28 \\
Banyak kelas interval & 9 & 9 & 8 \\
Interval & 14 & 11 & 5 \\
Rata-rata & 128,56 & 133,46 & 52,95 \\
Standar Deviasi & 24,98 & 19,72 & 5,52 \\
Median & 132,09 & 135,73 & 52,89 \\
Modus & 131,46 & 138,52 & 52,59 \\
Skor minimum ideal & 35 & 34 & 15 \\
Skor maksimum ideal & 175 & 170 & 75 \\
Rata-rata ideal & 105 & 102 & 45 \\
\hline Standar deviasi ideal & $\mathbf{2 3 , 3 3}$ & $\mathbf{2 2 , 6 7}$ & $\mathbf{1 0}$ \\
\hline
\end{tabular}

Keterangan :

$\mathrm{X}_{1}$ : Kepemimpinan Kepala Sekolah

$\mathrm{X}_{2}$ : Motivasi Kerja

$\mathrm{X}_{3}$ : Kinerja

Tabel 2 Distribusi Frekuensi Skor Kepemimpinan Kepala Sekolah

\begin{tabular}{ccccc}
\hline No & Kelas Interval & Frekuensi & Persentase (\%) & F Kumulatif (\%) \\
\hline 1 & $62,5-75,5$ & 3 & 1.24 & 1.24 \\
2 & $75,5-88,5$ & 16 & 6.64 & 7.88 \\
3 & $83,5-111,5$ & 31 & 12.86 & 20.75 \\
4 & $111,5-124,5$ & 43 & 17.84 & 38.59 \\
5 & $124,5-135,5$ & 51 & 21.16 & 59.75 \\
6 & $135,5-146,5$ & 44 & 18.26 & 78.01 \\
7 & $146,5-157,5$ & 31 & 12.86 & 90.87 \\
8 & $157,5-168,5$ & 15 & 6.22 & 97.10 \\
9 & $168,5-181,5$ & 7 & 2.90 & 100.00 \\
\hline \multicolumn{5}{c}{ Jumlah } \\
\hline
\end{tabular}

Tabel 2 menunjukkan bahwa skor tertinggi terletak pada kelas interval 168,5 - 181,5 sebanyak 7 orang $(2,90 \%)$, sedangkan skor terendah terletak pada kelas interval 62,5 - 75,5 sebanyak 3 orang (1,24\%). Frekuensi terbanyak yakni 51(21,16\%) orang terletak pada kelas interval 124,5-135,5, sedangkan sisanya sebesar $74,70 \%$ terdistribusi pada 6 kelas interval lainya.

Data yang terjaring dari 35 butir pertanyaan tentang kepemimpinan kepala sekolah yang dijawab oleh 241 responden menunjukkan adanya variasi atas beberapa pilihan jawaban. Pilihan jawaban responden menyebar dari pilihan jawaban selalu, sering, kadang - kadang, jarang dan tidak pernah. Dari pilihan jawaban responden kemudian dilakukan perhitungan berdasarkan rumus klasifikasi kategori. Diperoleh hasil kecenderungan jawaban responden tentang kepemimpinan kepala sekolah sebagai berikut. 
Data pada Tabel 3 menunjukkan bahwa sebanyak $18,67 \%$ respoden menyatakan bahwa kepemimpinan kepala sekolah tinggi atau sangat baik. Sebesar $63,07 \%$ responden menyatakan kepemimpinan kepala sekolah sedang atau baik, sisanya sebesar $46 \%$ menyatakan bahwa kepemimpinan kepala sekolah rendah atau kurang baik. Distribusi skor empirik untuk pernyataan kepemimpinan kepala sekolah menyebar antara skor terendah 63 sampai skor tertinggi 173.

\section{Motivasi Kerja}

Data variabel motivasi kerja (X2) terdiri dari lima indikator : 1). Lebih senang bekerja mandiri, 2). Cepat bosan dengan tugas yang rutin, 3). Dapat mempertahankan pendapatnya, 4). Percaya diri, dan 5). Senang mencari dan memecahkan masalah. Sebaran data dan distribusi frekuensi skor variabel motivasi kerja dapat dilihat melalui Tabel 4.

Tabel 4 menunjukkan bahwa skor tertinggi terletak pada kelas interval 161,5 - 171,5 sebanyak 14 orang $(5,81 \%)$, sedangkan skor terendah terletak pada kelas interval 81,5 - 91,5 sebanyak 6 orang $(2,49 \%)$. Frekuensi terbanyak yakni 50 (20,75\%) orang terletak pada kelas interval 131,5 - 141,5, sedangkan sisanya sebesar $71,95 \%$ terdistribusi pada 6 kelas interval lainya.

Data yang terjaring dari 34 butir pertanyaan tentang motivasi kerja yang dijawab oleh 241 responden menunjukkan adanya variasi atas beberapa pilihan jawaban. Pilihan jawaban responden menyebar dari pilihan jawaban selalu, sering, kadang-kadang, jarang dan tidak pernah. Dari pilihan jawaban responden kemudian dilakukan perhitungan berdasarkan rumus klasifikasi kategori. Diperoleh hasil kecenderungan jawaban responden motivasi kerja adalah sebagai berikut.

Data pada Tabel 5 di atas menunjukkan bahwa sebanyak $15,77 \%$ respoden menyatakan bahwa motivasi kerjanya sudah tinggi atau sangat baik. Sebesar $65,56 \%$ responden menyatakan motivasi kerjanya sedang atau baik, dan sisanya $18,67 \%$ menyatakan motivasi kerjanya dikategorikan rendah. Distribusi skor empirik untuk pernyataan motivasi kerja menyebar antara skor terendah 82 sampai skor tertinggi 170.

\section{Kinerja Guru}

Data variabel kinerja guru (X3) terdiri dari tiga indikator: 1). Perencanaan pembelajaran, 2). Pelaksanaan pembelajaran, dan 3). Penilaian pembelajaran. Sebaran data dan distribusi frekuensi skor variabel kompetensi kepribadian guru dapat dilihat melalui Tabel 6 .

Tabel 6 menunjukkan bahwa skor tertinggi terletak pada kelas interval 63,5-67,5 sebanyak 4 orang $(1,66 \%)$, sedangkan skor terendah terletak pada kelas interval 35,5 - 39,5 sebanyak 3 orang $(1,24 \%)$. Frekuensi terbanyak yakni $70(29.05 \%)$ orang terletak pada kelas interval 51,5 - 55,5, sedangkan sisanya sebesar $68,05 \%$ terdistribusi pada 5 kelas interval lainnya.

Data yang terjaring dari 15 butir penilaian tentang kinerja guru yang diberikan oleh pimpinan sekolah (penilai) terhadap 241 guru menunjukkan adanya variasi atas beberapa penilaian jawaban. Penilaian pimpinan sekolah terhadap kinerja guru menyebar dari pilihan jawaban skor $5,4,3,2$, dan 1. Dari penilaian jawaban tersebut kemudian dilakukan perhitungan berdasarkan rumus klasifikasi kategori diperoleh hasil kecenderungan penilaian tentang kinerja guru adalah sebagai berikut.

Data pada Tabel 7 menunjukkan bahwa sebanyak $17,43 \%$ penilai menyatakan bahwa kinerja guru sudah tinggi atau sangat baik. Sebesar $66,80 \%$ penilai menyatakan kinerja guru sedang atau memenuhi, dan sisanya $15,77 \%$ menyatakan kinerja guru dikategorikan masih rendah. Distribusi skor empirik untuk penilaian kinerja guru menyebar antara skor terendah 36 sampai skor tertinggi 64 .

Hasil perhitungan korelasi antara variabel kepemimpinan kepala sekolah dengan motivasi kerja berkorelasi sebesar 0,484 (cukup berarti) artinya jika kepemimpinan kepala sekolah tinggi, maka motivasi kerja guru tinggi (X1). Dari hasil perhitungan uji $t$ diperoleh $t$ hitung sebesar 9,761 dengan mengkonfirmasi harga $t$ hitung 9,761 dengan harga t tabel 1,97 pada taraf $\alpha=0,05$ ternyata hitung lebih besar dari t tabel. Dengan demikian hal ini menunjukkan bahwa kepemimpinan yang dimiliki kepala sekolah berpengaruh positif terhadap motivasi kerja guru. Demikian pula hasil perhitungan koefisien jalur menunjukkan bahwa pengaruh langsung kepemimpinan kepala sekolah 
Tabel 3 Tingkat Kecenderungan Responden tentang Kepemimpinan Kepala Sekolah

\begin{tabular}{cccc}
\hline Pilihan Jawaban & Skor & Frekuensi & Persentasi (\%) \\
\hline Tinggi & $\geq 154$ & 45 & 18,67 \\
Sedang & 104 s.d 154 & 152 & 63,07 \\
Rendah & $\leq 104$ & 44 & 18,46 \\
\hline Jumlah & & $\mathbf{2 4 1}$ & $\mathbf{1 0 0 , 0 0}$ \\
\hline
\end{tabular}

Tabel 4 Distribusi Frekuensi Skor Motivasi Kerja

\begin{tabular}{|c|c|c|c|c|}
\hline No & Kelas Interval & Frekuensi & Persentase $(\%)$ & F Kumulatif (\%) \\
\hline 1 & $81,5-91,5$ & 6 & 2.49 & 2.49 \\
\hline 2 & $91,5-101,5$ & 12 & 4.98 & 7.47 \\
\hline 3 & $101,5-111,5$ & 20 & 8.30 & 15.77 \\
\hline 4 & $111,5-121,5$ & 24 & 9.96 & 25.73 \\
\hline 5 & $121,5-131,5$ & 37 & 15.35 & 41.08 \\
\hline 6 & $131,5-141,5$ & 50 & 20.75 & 61.83 \\
\hline 7 & $141,5-151,5$ & 44 & 18.26 & 80.08 \\
\hline 8 & $151,5-161,5$ & 34 & 14.11 & 94.19 \\
\hline \multirow[t]{2}{*}{9} & $161,5-171,5$ & 14 & 5.81 & 100.00 \\
\hline & Jumlah & 241 & 100.00 & \\
\hline
\end{tabular}

Tabel 5 Tingkat Kecenderungan Pernyataan Responden Tentang Motivasi Kerja

\begin{tabular}{cccc}
\hline Pilihan Jawaban & Skor & Frekuensi & Persentase (\%) \\
\hline Tinggi & $\geq 153$ & 38 & 15,77 \\
Sedang & 144 s.d 153 & 158 & 65,56 \\
Rendah & $\leq 114$ & 45 & 18,67 \\
\hline Jumlah & & $\mathbf{2 4 1}$ & $\mathbf{1 0 0 , 0 0}$ \\
\hline
\end{tabular}

(X1) terhadap motivasi kerja (X2) sebesar 0,249 dan ternyata besar koefisien jalur tersebut $\geq 0,05$, sehingga Ho ditolak dan H1 tidak dapat ditolak. Hal ini menunjukkan bahwa kepemimpinan kepala sekolah berpengaruh positif terhadap motivasi kerja.

Begitu pula hasil perhitungan korelasi antara variabel kepemimpinan kepala sekolah dengan kinerja guru berkorelasi sebesar 0,488 (cukup berarti), Hal ini menunjukkan bahwa kepemimpinan kepala sekolah berpengaruh langsung terhadap kinerja guru. Dari hasil perhitungan uji t diperoleh $\mathrm{t}$ hitung sebesar 8,645 dengan harga $\mathrm{t}$ tabel 1,97 pada taraf $\alpha=0,05$ ternyata $t$ hitung lebih besar dari $t$ tabel. ). Dengan demikian dapat dinyatakan kepemimpinan kepala sekolah sangat berperan dalam upaya peningkatan kinerja guru SMA Negeri Kota Medan. Demikian pula hasil perhitungan koefisien jalur menunjukkan bahwa pengaruh langsung kepemimpinan kepala sekolah (X1) terhadap kinerja guru (X3) sebesar 0,156 dan ternyata besar koefisien jalur tersebut $\geq 0,05$, sehingga Ho ditolak dan $\mathrm{H} 3$ tidak dapat ditolak. Hal ini menunjukkan bahwa kepemimpinan kepala sekolah berpengaruh positif terhadap kinerja guru.

\section{Pembahasan}

Berdasarkan data hasil penelitian diketahui terdapat pengaruh positif langsung kepemimpinan kepala sekolah terhadap motivasi kerja guru. Besarnya kontribusi kepemimpinan kepala sekolah terhadap motivasi kerja guru adalah sebesar 0,249 atau $25 \%$. Hal ini berarti $25 \%$ motivasi kerja guru dipengaruhi oleh variabel kepemimpinan kepala sekolah, sedangkan 75\% lagi dipengaruhi oleh variabel lain di luar model. Temuan penelitian ini 
Tabel 6 Distribusi Frekuensi Skor Penilaian Pimpinan tentang Kinerja Guru

\begin{tabular}{ccccc}
\hline No & Kelas Interval & Frekuensi & Persentase(\%) & F Kumulatif (\%) \\
\hline 1 & $35,5-39,5$ & 3 & 1.24 & 1.24 \\
2 & $39,5-43,5$ & 8 & 3.32 & 4.56 \\
3 & $43,5-47,5$ & 27 & 11.20 & 15.77 \\
4 & $47,5-51,5$ & 56 & 23.24 & 39.00 \\
5 & $51,5-55,5$ & 70 & 29.05 & 68.05 \\
6 & $55,5-59,5$ & 47 & 19.50 & 87.55 \\
7 & $59,5-63,5$ & 26 & 10.79 & 98.34 \\
8 & $63,5-67,5$ & 4 & 1.66 & 100.00 \\
\hline \multicolumn{7}{c}{ Jumlah } & $\mathbf{2 4 1}$ & $\mathbf{1 0 0 . 0 0}$ & \\
\hline
\end{tabular}

Tabel 7 Tingkat Kecenderungan Penilaian Pimpinan Tentang Kinerja Guru

\begin{tabular}{cccc}
\hline Pilihan Jawaban & Skor & Frekuensi & Persentasi (\%) \\
\hline Tinggi & $\geq 58$ & 42 & 17,43 \\
Sedang & 47 s.d 58 & 161 & 66,80 \\
Rendah & $\leq 47$ & 38 & 15,77 \\
\hline Jumlah & & $\mathbf{2 4 1}$ & $\mathbf{1 0 0 , 0 0}$ \\
\hline
\end{tabular}

mendukung pendapat Colquitt, LePine dan Wesson (2009:26) yang menyatakan bahwa komunikasi kepala sekolah yang terkandung dalam model berpengaruh secara langsung terhadap motivasi kerja. Demikian juga dengan model keterampilan personal Whattson dan Cameron dalam Luthans (2006:288) yang menyatakan bahwa untuk memotivasi orang lain agar bekerja dengan baik, sangat dipengaruhi oleh kepemimpinan dalam berkomunikasi. Hal yang sama dikemukakan Owens (1987:84) yang menyatakan bahwa pimpinan dipandang sebagai seseorang yang memiliki kekuatan karena mampu mempengaruhi stafnya.

Penelitian ini menyimpulkan bahwa terdapat pengaruh langsung persepsi tentang kepala sekolah terhadap motivasi berprestasi. Sumbangan variabel kepemimpinan kepala sekolah terhadap motivasi kerja guru dapat diketahui melalui deskripsi data variabel kepala sekolah dimana $18,67 \%$ responden menyatakan penilaiannya terhadap kepemimpinan kepala sekolah tinggi atau sangat baik. Sebesar $63,07 \%$ responden menyatakan penilaiannya tentang kepala sekolah sedang atau baik, dan sisanya sebanyak $18,26 \%$ menyatakan bahwa kepemimpinan kepala sekolah rendah atau kurang baik. Data ini menunjukkan bahwa sebagian besar para guru SMA Negeri Kota Medan menilai bahwa kepemimpinan kepala sekolah dalam melakukan kepemimpinannya sudah cukup baik, sehingga tentunya hal ini dapat mempengaruhi motivasi kerja guru.

Hasil penelitian ini juga menunjukkan bahwa adanya pengaruh langsung kepemimpinan kepala sekolah terhadap kinerja guru telah dibuktikan dalam penelitian ini. Hasil estimasi menunjukkan koefisien jalur antara kepemimpinan kepala sekolah berpengaruh terhadap kinerja guru secara signifikan, dan besarnya kontribusi langsung tersebut sebesar 0,156 atau $16 \%$. Temuan ini memperkuat teori yang dikemukakan sebelumnya oleh Enuemel dan Egwunyenga (2008:94) menyimpulkan bahwa kepala sekolah yang menjalankan perannya dengan memberikan instruksi yang jelas kepada guru akan mempengaruhi kinerja guru. Gaya kepemimpinan yang efektif serta dapat memotivasi guru akan mampu menjadi dasar dan pondasi untuk meningkatkan kinerja guru yang akan berdampak pada peningkatan organisasi. Selain itu Obi (2002:13) menyatakan bahwa untuk menjadi kepala sekolah sekaligus pemimpin, kepala sekolah harus memberikan perhatian khusus pada program-program pengembangan guru yang akan berdampak pada meningkatnya kinerja guru.

Hasil penelitian yang dilakukan Ginting (2012:270) tentang hubungan kepemimpinan 
kepala sekolah dengan kinerja guru diperoleh hasil korelasi sebesar 0,719. Korelasi ini bernilai positif, yang berarti kenaikan pada indeks kepemimpinan kepala sekolah akan diikuti oleh kenaikan pada kinerja guru. Dari teori dan temuan hasil penelitian terdahulu dan dikaitkan dengan hasil penelitian yang diperoleh, jelas bahwa untuk meningkatkan kinerja guru SMA Negeri Kota Medan, dapat dilakukan dengan meningkatkan kepemimpinan kepala sekolah.

\section{KESIMPULAN DAN SARAN}

\section{Kesimpulan}

Simpulan dari penelitian ini adalah (1) Hubungan kepemimpinan kepala sekolah dengan motivasi kerja guru di SMA Negeri Kota Medan berdasrkan hasil penelitian dapat disimpulkan berada pada kategori cukup $(0,484)$. Kepemimpinan kepala sekolah berpengaruh langsung positif dan signifikan terhadap kinerja guru SMA Negeri Kota Medan sebesar 0,249 atau 25\%; dan (2) Hubungan kepemimpinan kepala sekolah dengan kinerja guru di SMA Negeri Kota Medan berdasarkan hasil penelitian dapat disimpulkan berada pada kategori cukup berarti yakni sebesar 0,488. Pengaruh langsung kompetensi kepribadian guru terhadap kinerja guru SMA Negeri Kota Medan Sebesar 0,156 atau $16 \%$.

\section{Saran}

Saran yang dapat diberikan: (1) Kepala Dinas Pendidikan dan Kebudayaan Kota Medan Perlu menyusun kebijakan dan program pembinaan kepada kepala sekolah dan guru untuk pengoptimalan dan pengkondisian peningkatan kompetensi kepribadian guru serta peningkatan motivasi kerja melalui kegiatan pelatihan dan workshop serta seminar bagi kepala sekolah dan guru SMA Negeri Kota Medan; dan (2) Kepala Sekolah SMA Negeri Kota Medan perlu melakukan penilaian / evaluasi terhadap kinerja guru disekolah masing-masing dan digunakan untuk kepentingan karier para guru sebagai persyaratan promosi jabatan, keikutsertaan dalam pendidikan dan pelatihan, sertifikasi guru, workshop, seminar, dan pemberian insentif yang berbasis kinerja

\section{DAFTAR RUJUKAN}

Colquitt, LePine, Wesson. 2009. Organizational Behaviour: Improving Performance And Commitment in The Workplace. New York: McGraw-Hill.

Effendy, O. C. 1981. Kepemimpinan dan Komunikasi. Bandung: Penerbit Alumni.

Enuemel, P. E., \& Egwunyenga, J.E. 2008. Principals' Instructional Leadership Roles and Effect on Teachers' Job Performance: A Case Study of Secondary Schools in Asaba Metropolis, Delta State, Nigeria. J. Soc. Sci., 16(1).

Ginting, B. 2012. Hubungan Budaya Organisasi Sekolah dan Kepemimpinan Kepala Sekolah Dengan Kinerja SMAN Kota Binjai. Skripsi: Tidak diterbitkan.

Griffin. 1997. Management. New Delhi : AITBS Publishers \& Distributor.

Hasibuan, S. P. M. 2001. Manajemen Sumber Daya Manusia. Jakarta: Bumi Aksara.

Kerlinger, N. F. 2006. Foundation of Beharioral Research 3rd Ed. Terjemahan Landung, S. Yogyakarta: UGM Press.

Locke, E. A. 1997. Esensi Kepemimpinan (terjemahan). Mitra Utama.

Luthans, F. 2006. Prilaku organisasi edisi kesepuluh. Alih Bahasa: Vivin Andika Yuwono dkk.Yokyakarta: Andi.

Minner. 1992. Industrial Organizational Psychology. New York: McGraw- Hill.

Obi, E. 2002. "Motivation and Organisational Behaviour". Administration and Management Onitsha: Meks Publishers Ltd.

Owens, R. G. 1991. Organizational Behavior in Education. Boston: Allyn and Bacon.

Robbins, S. P. 2001. Perilaku Organisasi Jilid I. Yogyakarta: Aditya Media Ilmu.

Undang-Undang Republik Indonesia Nomor 20 Tahun 2003 tentang Sistem Pendidikan Nasional. 2010. Bandung: Citra Umbara. 